\title{
Premature mammary development in ewe lambs exposed to an oestrogenic lucerne pasture
}

\author{
R.L. FIELDS, G.K. BARRELL and D.J. MOOT \\ Faculty of Agriculture and Life Sciences, PO Box 85804, \\ Lincoln University, Lincoln 7647, Christchurch, New Zealand \\ Rachel.Fields@lincolnuni.ac.nz
}

\begin{abstract}
A report of mammary development in 6-month-old ewe lambs grazing lucerne on a commercial farm in North Otago provided an opportunity to investigate the possibility to use this as a tool to detect oestrogenic lucerne pastures. Of the 36 ewe lambs grazing lucerne at this farm, protruding mammary glands were visible in 19. In contrast, none of the 22 ewe lambs grazing grass had protruding mammary glands. The lucerne-fed ewe lambs also had larger mean teat width than the grassfed ewe lambs $(17.9 \pm 0.53 \mathrm{~mm}$ versus $13.4 \pm 0.78 \mathrm{~mm}$ respectively. The lucerne-fed animals were returned to grass pasture 4 weeks before the introduction of rams. There was no effect of the earlier 16 weeks of lucerne grazing on the number of fetuses present in ewes near mid-gestation compared with ewes on grass throughout this period. These findings from a commercial farm suggest that oestrogenic lucerne may be detected by monitoring ewe lambs for mammary development. This would enable farmers to manage pre-mating grazing of ewes with minimal risk of lowered ovulation rates.
\end{abstract}

Keywords: sheep, coumestrol, oestrogen, fecundity, Medicago sativa, alfalfa

\section{Introduction}

In New Zealand dryland systems, lucerne (Medicago sativa $\mathrm{L}$.) is used by many farmers to increase pre-mating liveweight of ewes and replacement ewe lambs, as increased liveweight has a beneficial effect on ovulation rate (Thompson et al. 1990). However, this benefit can be confounded by the negative effects on ovulation rate arising from the occurrence of the phyto-oestrogen, coumestrol, in this plant species (Coop 1977).

Coumestrol, can vary between $0-600 \mathrm{ppm}$ in lucerne herbage, with highest concentrations occurring in diseased plant material (Hanson et al. 1965; Smith et al. 1979). Coumestrol levels of $25 \mathrm{ppm}$ in forage have been reported as sufficient to reduce ovulation rate in ewes (Smith et al. 1979). In New Zealand, there is evidence that lucerne forages grazed before and during mating have caused lowered ovulation rate in ewes, leading to 10 to $30 \%$ fewer multiple births on lucerne than grass pastures (Coop 1977; Scales et al. 1977; Smith et al. 1979).
Currently there is inadequate information for provision of advice to sheep farmers on how to manage this potential threat to reproductive performance of their flocks. The most conservative approach is to remove sheep from lucerne crops during the pre-mating period. However, the withholding period is unknown and removal can impair liveweight gain unnecessarily if coumestrol is not present at high levels in the herbage. Thus, guidelines need to be developed to assist farmers in making decisions about grazing in the pre-mating period.

Teat growth has previously been reported in wethers grazing oestrogenic lucerne (Newton \& Betts 1968) but not in ewe lambs. This paper reports on an incident where ewe lambs grazing lucerne on a commercial sheep farm had premature mammary and teat development. The paper outlines the on-farm monitoring that was undertaken through to pregnancy scanning to determine subsequent ewe reproductive performance.

\section{Methods}

Sheep were cross-bred ewe lambs of predominantly Texel-East Friesian-Coopworth ancestry held on a commercial farm, 'Creedmoor', located $17 \mathrm{~km}$ southwest of Oamaru, North Otago, New Zealand. They were born in spring 2014 and at weaning on 27 November 2014 any with a liveweight below $32.5 \mathrm{~kg}$ were allocated a lucerne crop $(n=36)$. Those with higher liveweights were returned to a predominantly ryegrass/ white clover pasture $(\mathrm{n}=22)$. The average liveweights were $25.1 \pm 0.84 \mathrm{~kg}$ for sheep on lucerne and $34.7 \pm$ $0.41 \mathrm{~kg}$ for those grass-based. This allocation was a commercial management decision intended to provide a superior nutrient supply to the lighter lambs. Lambs assigned to lucerne were 9 days younger than lambs assigned to grass $(\mathrm{P}<0.001)$. The average date of birth $( \pm$ SEM) was 3 September $2014 \pm 0.9$ days and 12 September $2014 \pm 1.6$ days for grass- and lucerne-fed lambs, respectively.

Throughout post-natal growth the lambs received routine husbandry treatments for endo- and ectoparasites, anti-clostridial vaccinations and vitamin supplements. Their fleeces were shorn on 2 March 2015. Liveweight was measured with electronic scales at weaning (27 November 2014), pre-shearing (2 March 2015), on 12 March 2015, and at commencement of 
mating (20 April 2015).

On 12 March and 16 April 2015, all ewe lambs were checked by palpation for protruding mammary glands. Measurements of teat length, teat width at the base and mammary gland diameter were recorded using a digital calliper for 22 of the lucerne-fed ewe lambs and for 10 of the grass-fed lambs selected randomly. For each lamb, data for right and left teat measurements were averaged to give a single value.

On 20 March 2015, sheep were removed from the lucerne crop and re-united with their grass-fed cohorts on the grass-based pasture. A vasectomised ram was placed with the ewe mob on 9 April 2015 and remained there for 2 weeks before being replaced with a crayonharnessed entire ram from 20 April 2015. Crayon marking of the ewes was recorded and the number of fetuses present was determined by transabdominal ultrasound recording, carried out by a commercial operator on 24 June 2015.

Plant samples were collected on 12 March 2015 from the grass-based pasture and the lucerne paddocks used in the grazing rotation. Samples were oven-dried, ground and $0.5 \mathrm{~g}$ extracted with $5 \mathrm{~mL}$ methanol. Extracts were analysed for coumestrol content using HPLC with methodology adapted from Wang et al. (1990). HPLC analyses were performed with an Agilent 1100 series instrument (Agilent Technologies, San Francisco, CA, USA) equipped with binary pumps, and a fluorescence detector set at $365 \mathrm{~nm}$ for excitation and $418 \mathrm{~nm}$ for emission. The injection volume was $20 \mu \mathrm{L}$. Separation was carried out on an ACE reverse phase column $(\mathrm{C} 18$, $3 \mu \mathrm{m}, 150 \mathrm{~mm} \times 2.1 \mathrm{~mm})$ at $25^{\circ} \mathrm{C}$, with the flow rate set at $0.5 \mathrm{~mL} / \mathrm{min}$. Solvent A was deionized water and solvent B was $100 \%$ methanol. Elution of coumestrol was performed using the following gradient sequence: $40 \% \mathrm{~B}$ at 0 minutes, 12 minutes at $60 \% \mathrm{~B}, 16$ minutes at $80 \% \mathrm{~B}$, and 20 minutes at $100 \% \mathrm{~B}, 100 \% \mathrm{~B}$ kept for 2 minutes, the column was equilibrated for 8 minutes between samples. Coumestrol (Sigma-Aldrich, St. Louis, MO) was used to make a calibration curve from 0.5 to 20 $\mathrm{ppm}$. The inter-assay $\mathrm{CV} \%$ for this method was $4.2 \%$.

Data were analysed in Minitab 17. Two-sample $t$-tests were used to compare the two treatment groups for liveweight at each weighing. Regression models were used to account for the effects of diet, liveweight, growth rate, birth rank and age on mammary presence, teat width, teat length and the number of foetuses/ ewe at scanning. These models were built with terms through order two and stepwise regression $(\alpha$ to enter $=$ $0.15)$. Data are presented as mean \pm SEM.

\section{Results}

\section{Liveweight}

At weaning (27 November 2014), the lambs about to be transferred to lucerne were lighter than the lambs remaining on grass $(25.1 \pm 0.84 \mathrm{~kg}$ versus $34.7 \pm 0.41$ $\mathrm{kg} ; \mathrm{P}<0.001)$. The lambs on lucerne remained lighter than lambs on grass with mean liveweights of $45.4 \pm$ $0.98 \mathrm{~kg}$ and $53.2 \pm 0.58 \mathrm{~kg}$ on 12 March 2015, which was towards the end of the lucerne grazing period (20 March). Between weaning and shearing (2 March 2015) the average daily liveweight gains for lucerne and grass-fed lambs were $215 \pm 4.5 \mathrm{~g}$ and $198 \pm 6.1 \mathrm{~g} /$ day $(\mathrm{P}=0.032)$.

Between 12 March 2015 and mating (20 April 2015) ewe lambs fed lucerne for the first 8 days followed by 31 days of grass had a higher gain in liveweight than the grass-fed lambs. During this period liveweight gain was $195 \pm 7.4 \mathrm{~g} /$ day for lucerne-fed lambs moved to grass and $110 \pm 4.5 \mathrm{~g} /$ day for grass-fed lambs $(\mathrm{P}<0.001)$.

At mating, lambs previously fed lucerne were still lighter $(\mathrm{P}<0.01)$ than grass-fed lambs $(53.0 \pm 1.01 \mathrm{~kg}$ versus $57.5 \pm 0.60 \mathrm{~kg})$.

\section{Mammary development}

On 12 March 2015, there was substantial mammary and teat development in some of the ewe lambs that grazed lucerne (Figure 1). Protruding mammary glands were present in 19 of the 36 lucerne-fed lambs and in none of the grass-fed lambs. Mammary gland protrusion was related to grazing treatment $(\mathrm{P}<0.001)$ and not related to birth rank, age, current liveweight or growth rate between weaning and 12 March 2015. The mean diameter of protruding mammary glands was $61.1 \pm 2.8$ $\mathrm{mm}$.

Lucerne-fed ewe lambs had a greater mean teat width than grass-fed lambs $(17.9 \pm 0.53 \mathrm{~mm}$ versus $13.4 \pm$ $0.78 \mathrm{~mm}$, respectively, $\mathrm{P}=0.004)$. There was a possible relationship between weaning to 12 March 2015 growth rate and teat width $(\mathrm{P}=0.06)$, where lambs that had put on more weight during this period tended to have larger teat widths.

Mean teat length of the lambs was $22.1 \pm 0.50 \mathrm{~mm}$ and there was no effect of grazing treatment $(\mathrm{P}=0.783)$. Teat length was related to the growth rate of lambs between weaning and 12 March $2015(\mathrm{P}=0.001)$.

Three weeks after lucerne-fed lambs were moved to grass (16 April 2015) there had been no change in mammary size $(\mathrm{P}=0.104)$ compared to 12 March 2015. Grass-fed lambs had a greater increase in teat width between 12 March and 16 April 2015 than exlucerne-fed lambs $(5.5 \pm 0.81 \mathrm{~mm}$ versus $0.9 \pm 0.51$ $\mathrm{mm}, \mathrm{P}<0.001)$. Mean teat widths of the ex-lucerne and grass-fed lambs were no longer different $(18.9 \pm 0.58$ $\mathrm{mm}$ and $19.0 \pm 0.93$, respectively, $\mathrm{P}=0.966$ ).

On 16 April 2015, the mean teat length had decreased, relative to 12 March 2015, to $20.4 \pm 0.49 \mathrm{~mm}(\mathrm{P}=0.039)$ and there was still no difference in mean teat length between ex-lucerne-fed and grass-fed lambs $(\mathrm{P}=0.116)$.

In this study there was no effect of birth rank, age 

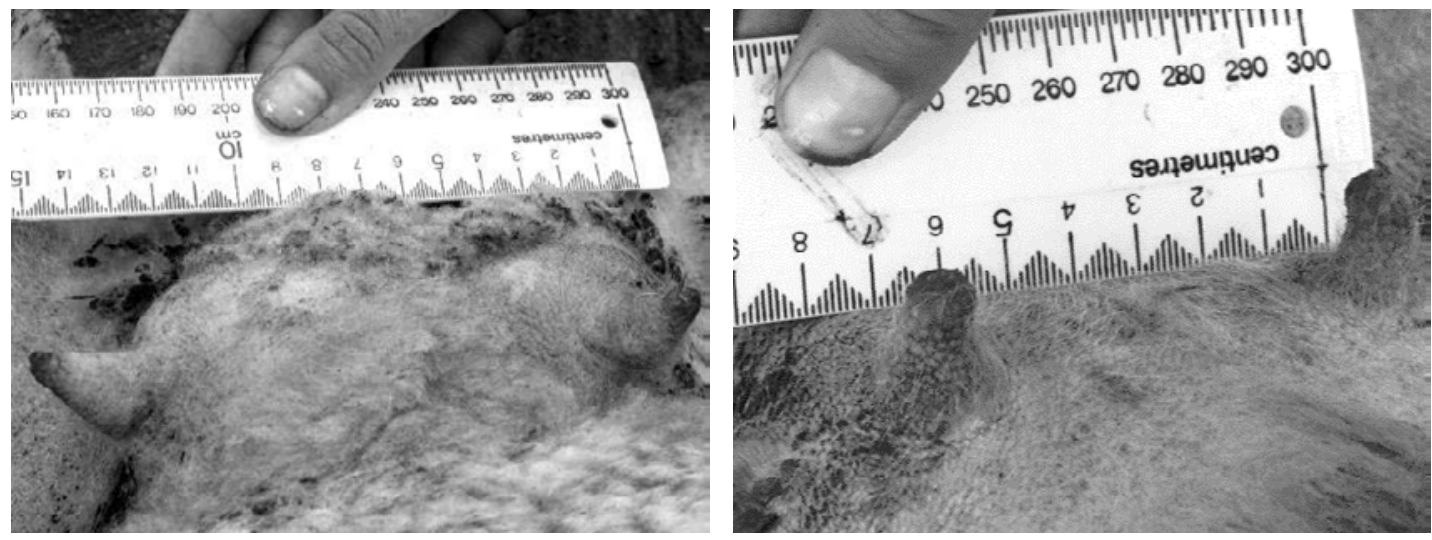

Figure 1

Mammary gland and teat development of a ewe that had grazed lucerne (left) in comparison with one that had grazed a ryegrass/white clover pasture (right). Photographs taken 12 March, 2015.

or liveweight at time of measurement on teat size $(\mathrm{P}>0.100)$.

\section{Reproductive performance}

All animals were marked during the mating period, suggesting that there was no effect of the earlier grazing of lucerne by post-weaning pre-pubertal lambs on mating activity compared with grazing of grass (as gauged from crayon marking by rams).

There was a relationship between liveweight and the number of fetuses present/ewe near mid-gestation $(\mathrm{P}<0.001)$. The grass-fed ewe lambs were on average $4.5 \mathrm{~kg}$ heavier in liveweight and had a greater number of fetuses/ewe compared with the ex-lucerne-fed animals $(2.05 \pm 0.10$ versus $1.66 \pm 0.10 ; \mathrm{P}=0.026)$.

All grass-fed animals $(\mathrm{n}=22)$ had a liveweight above $53 \mathrm{~kg}$. When results from the fetal scanning data for the grass-fed animals were compared with those of the ex-lucerne-fed animals weighing over $53 \mathrm{~kg}(\mathrm{n}=19)$ there was no difference in the mean liveweight of the selected animals $(57.5 \pm 0.6 \mathrm{~kg}$ and $57.8 \pm 0.7 \mathrm{~kg}$, for grass- and ex-lucerne-fed ewes, respectively). There was no difference in the proportion of multiple births between grazing treatments with $89 \%$ of ex-lucernefed and $91 \%$ of grass-fed ewes having two or more fetuses present $(\mathrm{P}=0.834)$. There was no difference in the total number of fetuses present/ewe $(1.95 \pm 0.14$ and $2.05 \pm 0.10$ fetuses for ex-lucerne- and grass-fed animals, respectively, $\mathrm{P}=0.581$ ). There was also no relationship between 12 March to 20 April 2015 growth rate and number of fetuses present in pregnant animals $(\mathrm{P}=0.894)$.

\section{Pasture coumestrol levels}

On 12 March 2015, lucerne in non-grazed stands of the crop was mature, at a late flowering/early seed set development stage. Fungal diseases, namely spring black stem (Phoma medicaginis) and Stemphylium botryosum were present in the stands. Coumestrol content of the lucerne was $77.1 \pm 2.2 \mathrm{mg} / \mathrm{kg} \mathrm{DM}$ for the material being grazed by the ewe lambs in this study on 12 March 2015. In the residual stems of the previously grazed lucerne stand, which the ewe lambs were removed from on 6 March 2015, the coumestrol content was $55.8 \pm 2.9 \mathrm{mg} / \mathrm{kg}$ DM. In the lucerne stand the ewe lambs were moved to on 13 March 2015, the coumestrol content was $76.9 \pm 6.3 \mathrm{mg} / \mathrm{kg}$ DM. The grass-based pasture had $0.2 \mathrm{mg} / \mathrm{kg} \mathrm{DM}$.

\section{Discussion}

Mammary gland protrusion and increased teat width were observed in ewe lambs grazed on lucerne pastures, while their cohorts grazed on grass did not show these developments.

Animals were allocated to grazing treatments at weaning as a commercial management decision to provide the lighter ewe lambs a higher quality diet than the heavier lambs. Between 27 November 2014 and 2 March 2015 the ewe lambs on the lucerne had a 17 g greater average daily liveweight gain than the ewe lambs on grass. Despite this, the grass-fed ewe lambs remained heavier throughout the observational period.

A between-group difference in liveweight could affect teat and mammary development. However, mammary development is typically isometric with liveweight in non-pregnant ewe lambs (Johnsson \& Hart 1985). A previous study that measured mammary development in 4- and 8-month-old pre-pubertal lambs showed greater mammary fat pad mass in the heavier animals (Johnsson \& Hart 1985). This means that in the present on-farm study the larger lambs on grass would be expected to have larger teats and greater mammary development than the smaller lambs on lucerne, which was not the case. Age and birth rank also did not account for the mammary gland and teat development that were observed. Therefore, the mammary gland and 
teat development of the ewe lambs grazing lucerne, and the lack of this development in lambs grazing grass, was most likely due to the presence of biologically active phyto-oestrogens in the grazed lucerne.

The lucerne had a coumestrol content above the level of $25 \mathrm{ppm}$ DM reported as sufficient to cause a negative impact on ovulation rate (Smith et al. 1979). Removal of the putatively oestrogen-affected ewe lambs from the lucerne crop and their re-location to a grass-based pasture 4 weeks before mating appeared to allow recovery from any potential negative impact of the plant oestrogens on the subsequent numbers of fetuses produced when animals within a similar liveweight range were compared. However, removed animals also had greater liveweight gain in the 5 weeks before mating than the grass-fed animals which may account for some of the similarity in the numbers of fetuses produced by each group.

It is concluded that premature mammary and teat development in ewe lambs is an indicator of oestrogenicity of grazed lucerne. Further experimentation where treatment groups are randomly assigned or balanced for liveweight will be required to fully validate this finding. Transfer of sheep grazing oestrogenic lucerne to a grass-based pasture a month before mating may overcome possible detrimental effects on their reproductive performance. However, further research is required to test this and also to determine how long animals should be removed from an oestrogenic pasture before mating to avoid compromising reproductive performance.

\section{ACKNOWLEDGEMENTS}

We are indebted to Julian and Sharyn Price for alerting us to the occurrence of mammary development in their ewe lambs and for co-operation with the collection of data for this study. Martin Wellby and Lisa PeersAdams are thanked for technical assistance. Beef + Lamb New Zealand are acknowledged for their financial contribution towards this study.

\section{REFERENCES}

Coop, I.E. 1977. Depression of lambing percentage from mating on lucerne. Proceedings of the New Zealand Society of Animal Production 37: 149-151.

Hanson, C.H.; Loper, G.M.; Kohler, G.O.; Bickoff, E.M.; Taylor, K.W.; Kehr, W.R.; Stanford, E.H.; Dudley, J.W.; Pedersen, M.W.; Sorenson, E.L.; Carnahan, H.L.; Wilsie, C.P. 1965. Variation in coumestrol content of alfalfa as related to location, variety, cutting, year, stage of growth, and disease (Technical Bulletin No. 1333). US Department of Agriculture, Washington, DC.

Johnsson, I.D.; Hart, I.C. 1985. Pre-pubertal mammogenesis in the sheep 1 . The effects of level of nutrition on growth and mammary development in female lambs. Animal Production 41: 323-332.

Newton, J.E.; Betts, J.E. 1968. Seasonal oestrogenic activity of various legumes. The Journal of Agricultural Science 70: 77-82.

Scales, G.H.; Moss, R.A.; Kelly, R.W. 1977. Reproductive performance of ewes mated on lucerne. New Zealand Society of Animal Production 37: 152157.

Smith, J.F.; Jagusch, K.T.; Brunswick, L.F.C.; Kelly, R.W. 1979. Coumestans in lucerne and ovulation in ewes. New Zealand Journal of Agricultural Research 22: 411-416.

Thompson, K.F.; Sedcole, J.R.; O'Connell, D.; Geenty, K.G.; Sykes, A.R. 1990. Spring and summer pasture feeding and ewe reproduction and wool growth. Proceedings of the New Zealand Grassland Association 52: 123-127.

Wang, G.; Kuan, S.S.; Francis, O.J.; Ware, G.M.; Carman, A.S. 1990. A simplified HPLC method for the determination of phytoestrogens in soybean and its processed products. Journal of Agricultural and Food Chemistry 38: 185-190. 